\title{
CARD11 wt Allele
}

National Cancer Institute

\section{Source}

National Cancer Institute. CARD11 wt Allele. NCI Thesaurus. Code C60669.

Human CARD11 wild-type allele is located within 7p22 and is $138 \mathrm{~kb}$ in length. This allele, which encodes caspase recruitment domain-containing protein 11, plays a role in apoptosis regulation and signal transduction. 